\title{
Factors Influencing Consumer Intentions to Adopt Online Banking in Malaysia
}

\begin{abstract}
Aftab Parvez Khan ${ }^{1}$, Shahnawaz Khan², Ivan Ang Ri Xiang
Abstract

As the world gradually shifts to the technological age, the number of digital savvy consumers has been growing exponentially. Such trends would eventually translate to increased consumer demand for digital related services such as online banking. Since online banking offers a number of benefits to the banking sector, therefore, banks need to deeply understand the factors which influence consumer intentions in adopting online banking. This paper investigates some of the most significant factors influencing consumers' intentions to adopt online banking in the Malaysian context. A survey is conducted for this purpose and a sample of 200 respondents is chosen which includes male and females in equal proportions. Self-administered questionnaire is used for data collection. Seven factors are identified to have impact on the consumer intentions in adopting online banking. Four of them are found to have significant impact on consumer intentions which are convenience, trust, perceived ease of use, and perceived usefulness; whereas, the rest of the factors, i.e. social influence, gender and age group, do not impact consumer intentions in adopting online banking. The study has implications for banks which provide online facilities and those who plan to go online. Further, the study has implications for policy makers who intend to promote online environment as the study reveals some of the major factors which need due consideration in this respect.
\end{abstract}

Keywords: Online banking, consumer intentions, convenience, trust, usefulness, ease, social influence, Malaysia

\section{Introduction}

Since the early eras, banks have always played a central role in the development of many world economies by acting as the facilitator of economic growth and instigator of infrastructure developments. However, as the world continues to modernize, traditional banking formats are no longer sufficient to serve the needs and demands of

1 Assistant Professor, Institute of Management Sciences, Peshawar. Email: aftab.parvez@hotmail.com 2 Assistant Professor, Institute of Management Sciences, Peshawar. Email: shahnawaz.khan@imsciences. edu.pk

\begin{tabular}{lll} 
ARTICLE HISTORY & & \\
14 Nov, 2016 Submission Received & 24 Nov, 2016 & First Review \\
\hline 12 Dec, 2016 Revised Version Received & 16 Jan, 2017 & Second Review \\
\hline 5 Feb, 2017 Revised Version Received & 19 Feb, 2017 & Accepted
\end{tabular}


evolving consumers. In various parts of the world, physical bank branches with the usual automated machines and banking officers have been found to be inadequate in solving consumer cravings for faster banking services to suit their rapid lifestyles.

Over the past decade, internet has been very pivotal in spurring the growth of online banking, as observed most convincingly in emerging markets. As shown in Figure 1 , it is evident that online banking is continually growing along with higher internet penetration rates in various emerging economies (Euromonitor International, 2015). This paper, therefore, investigates the factors that influence consumer intentions in adopting online banking. Since the use of internet banking has grown exponentially as mentioned earlier. This paper would help highlight those factors that influence consumer intentions in adopting online banking.

Web Use Drives Banking Internet Users

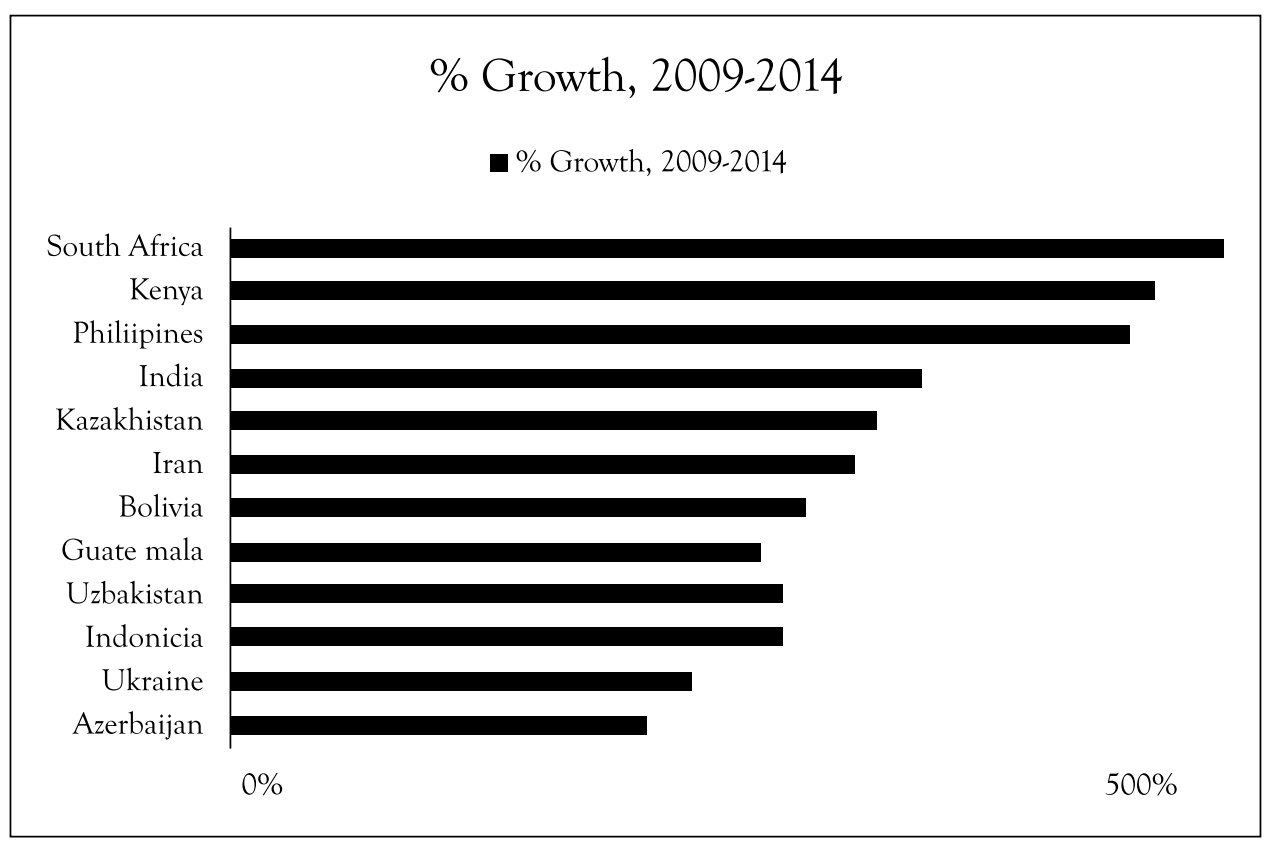

Banking Catches on in Emerging Regions

Banked population as \% of $15+$ population 


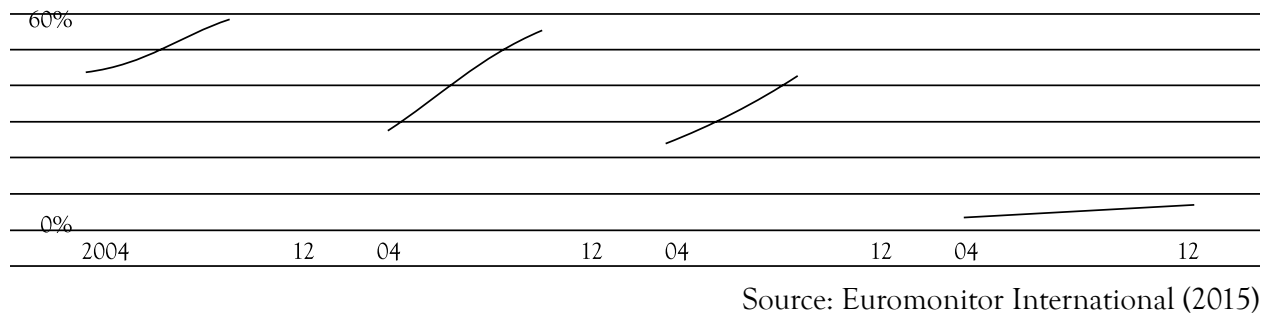

Figure 1: Growth of the Internet and Online Banking in Emerging Regions

In Asia, the increased adoption of online banking is also mainly due to the migration of rural consumers to populated cities with modern telecommunications infrastructure and internet technologies. However, according to Foon and Fah (2011), an increase in the number of internet users would apparently bring a corresponding rise in the usage and adoption of online banking. Pertaining to this, the number of internet users in Malaysia as documented at June 2012 was already at 17.72 million, or approximately $60.7 \%$ of the total population (Internet World Stats, 2012). While these numbers seem to rather aligned with the number of subscribers of internet banking, there seems to be a great opportunity to increase the exposure and adoption rate of mobile banking in the Malaysian market.

The growth and global prominence of the online banking platform across different nations, emerging and developed ones alike, has attracted a lot of attention especially those who are engaged in the banking and financial sector. Along with this, a plethora of studies and research has since surfaced, all with the intent to understand online banking in a deeper and more meaningful sense, albeit from different points of view.

Consequently, such studies have been particularly useful in providing preliminary insights, especially in the Malaysian context where the online banking sector is still predicted to grow by several folds in the coming years. According to several authors (Pikkarainen, Pikkarainen, Karjaluoto, \& Pahnila, 2004; Cheng, Lam, \& Yeung, 2006), the Technology Acceptance Model (TAM) proposed by Davis (1989) is the most widely used framework to predict the adoption and acceptance of new technologies, and it has proven to be instrumental in measuring the adoption of online banking (Vijayasarathy, 2003). By applying the TAM model, many authors found the factors of perceived usefulness and perceived ease of use to be important antecedents of intentions to adopt online banking (Cheah, Teo, Sim, Oon, \& Tan, 2011; Chung \& Kwon, 2009; Lee, McGoldrick, Keeling, \& Doherty, 2003; Kim, Chan, \& Gupta, 2007; Luarn \& Lin, 2005). Additionally, research also shows that the adoption of online banking is well predicted by the many benefits that it brings (Chan \& Lu, 2004), with factors such as convenience (Gikandi \& Bloor, 2010), faster transactions (Jayawardhena \& Foley, 2000), lower fees and charges (Siriluck 
\& Speece, 2003; Jun \& Cai, 2001), and reliable service (Al-Hawari \& Ward, 2006), amplifying usage intentions.

However, in spite of the many advantages that are inherent in the online banking platform, there is still a large group of individuals who refuse to adopt this service altogether for reasons unknown (Littler \& Melanthiou, 2006; Kuisma, Laukkanen, $\&$ Hiltunen, 2007). And despite the rich number of studies across different nations and various focal areas, there seems to be a lack of consensus on the most important facilitating or inhibiting factors towards online banking in Malaysia. Hence, it is without a doubt that there is considerable amount of room for which more knowledge and insights can be explored on this topic area (Abu Shanab \& Pearson, 2007; Shanmugam \& Guru, 2000). Besides, bank marketers and senior managers are also particularly intrigued about uncovering more information on the important aspects of an online banking platform that can elevate its growth or decide its demise (Lee, 2003; Yiu, Grant, \& Edgar, 2007; Jarvenpaa, Tractinsky, \& Saarinen, 1999). Besides, a bulk of studies on online banking has also failed to address one of the most important components, which is the demographics of the consumers and if there are significant differences to the way each group reacts towards this platform. Therefore, in light of the gaps in the existing literature, there is a need for the online banking situation in Malaysia to be studied in a more holistic and complete manner.

Having already detailed some of the general findings and existing gaps in the literature on online banking, The objective of this paper is to identify the most significant antecedents of consumer intentions to use/adopt internet/mobile banking and to develop a holistic framework that captures factors known to affect consumer usage intentions of online banking based on various aspects like the TAM, system characteristics, consumer attitudes, and demographic variables

Referring to the objectives, three questions to be addressed by this study are as follows: What are the antecedents of consumer intentions to use/adopt internet and mobile banking? Are there any significant differences in online banking usage intentions for consumers of different genders? Are there any significant differences in online banking usage intentions for consumers of different age groups?

\section{Literature Review}

Retail banks are now shifting their focus towards developing digital channels as proposed by Davis (1989), the Theory of Reasoned Action (TRA) by Fishbein and Ajzen (1975), and the Theory of Planned Behavior proposed by Ajzen (1991). 


\subsection{Theoretical Grounds}

The TAM framework is one of the most cited models in the predictive acceptance of new information technology and computerized systems within organizations, which hypothesizes that the use of a system or technology is well determined by the behavioral intentions of the consumers (Nasri, 2011). This theory posits that the likelihood of system usage is governed by the constructs of perceived usefulness and perceived ease of use, which refers to how the consumer perceives that using that specific system would enhance his/her task outcome and the extent to which the use of the system is free of effort respectively (Davis, 1989). According to Vijayasarathy (2003), these 2 constructs have also been critically proven to be important determinants of consumer intentions to adopt online banking. With the adaptation of this framework to various studies, other scholars (Chin \& Todd, 1995; Adams, Nelson, \& Todd, 1992; Doll, Henddrickson, \& Deng, 1998) agree as well that the TAM is well suited in predicting an individual's acceptance of numerous new technologies. However, the TAM is regarded by certain quarters to be insufficient in fully explaining consumer decisions to adopt online banking, because this framework only takes into account the technological aspects of the online banking system and thereby neglects other parameters such as psychological and social features that could also influence the uptake decision (Wang, Wang, Lin, \& Tang, 2003; Lai \& Li, 2005; Cheng et al., 2006; Gounaris \& Koritos, 2008).

As a result of that, several authors have advocated the additional use of the TRA and TPB model to explain the acceptance of online banking (Yaghoubi \& Bahmani, 2010; Nasri, 2011). According to Venkatesh, Morris, Davis, and Davis (2003), the TRA is one of the effective models in explaining actual human behavior via the constructs of attitude and subjective norm. The attitude construct refers to an individual's evaluative feelings (positive and negative) towards executing the target behavior, while subjective norm denotes the extent to which individuals think that the target behavior should or should not be carried out based on the perceptions of the people within their social circle (Fishbein \& Ajzen, 1975). The TPB was later developed as an extension of the TRA, which holsters the additional construct of perceived behavioral control, which reflects an individual's perceptions about the relative ease or difficulty of performing the target behavior, and how they view the internal and external limitations surrounding the behavior (Ajzen, 1991). Together, the TRA and TPB focus on using behavioral intentions of individuals to explain their actual behavior (Nasri, 2011). According to Ajzen (1991), various studies have proven the applicability of the TPB model to numerous current domains. Besides, the TPB is also an adept framework for explaining and measuring the acceptance of a new technology, through the investigation of the individual's intentions towards 
adoption (Yaghoubi \& Bahmani, 2010). Such sentiments have been documented in telemedicine technology studies ( $\mathrm{Hu}$, Chau, \& Sheng 2002), computer resource uptake (Taylor \& Todd, 1995), IT acceptance in work settings (Venkatesh \& Davis, 2000), adoption of electronic brokerage services, and general acceptance of online banking (Liao, Shao, Wang, \& Chen, 1999). In fact, Conner and Abraham (2001) and Alegre and Cladera (2009) further commented that the inclusion of additional factors or constructs to the TPB model can enhance its predictive capability.

Additionally, Hoppe, Newman, and Mugera (2001) also argued that the use of intentions to be a sound measure of predicting actual behavior. Such views are shared by Morwitz, Steckel, and Gupta (2006) and Morrison (1979), citing the aspect of intentions to be highly accurate in gauging actual consumer behavior. According to Chang and Liu (2009), the reason for the popular use of intentions is probably because it is a plan to carry out a future behavior where a considerable amount of thought is attributed to the act itself. These interpretations are well substantiated, especially since most studies in the topic area (Maditinos, Chatzoudes, \& Sarigiannidis, 2013; Poon, 2007; Ndubisi \& Sinti, 2006; Chong, Ooi, Lin, \& Tan, 2010; Ong \& Cheng, 2003; Rouibah, 2012; Wang \& Pho, 2009) also implemented the use of consumer intentions as the instrument to measure the acceptance of online banking. The following sections provide a brief discussion on the factors affecting intentions to adopt online banking leading to the presentation of the hypothesis at the end of each section.

\subsection{Convenience and Intention to Adopt Online Banking}

Since the study is based on TRA and TPB models where one of the assumptions in adopting a new technology is perceived convenience in the use of a new technology. This section therefore, briefs out a number of empirical studies where convenience has played its role in the adoption of a new technology.

One factor that is widely accepted as a good predictor of the acceptance of new innovation technologies is that of convenience (Ramsay \& Smith, 1999; Nielsen, 2005). According to Black, Lockett, Winklhofer, and McKechnie (2002), the domain of convenience is also well adapted to online banking studies. Similarly, Eastin (2002) also found in his study that perceived convenience emerged as the most significant factor in predicting consumer usage of online banking. In line with that, there are many aspects of online banking that contribute to the idea of convenience. Such aspects include 24-hour service availability (Liao \& Cheung, 2002; Gerrard \& Cunningham, 2003), access across different geographical borders (Liao \& Cheung, 2002), time savings (Lichtenstein \& Williamson, 2006; Singhal \& Padhmanabhan, 2008), and the vast variety of services provided (Liao \& Cheung, 2002). 
Among these aspects, the facet of accessibility has received considerable attention from researchers in the online banking literature. According to Potaloglu and Ekin (2001), most consumers cite the convenience of online banking channels as opposed to the traditional format mainly because it allows them to access basic banking functions from any location and at any time, which greatly enhances the time they save and their personal efficiencies. The work of Rotchanakitumnuai and Speece (2003) and Raman and Don (2013) substantiates this, as they argue that online banking has a far more advanced ability to reach consumers residing in various geographies and reduce their waiting time for performing transactions. The study of Poon (2007) also revealed the factor of convenience to one of the most important factors in determining consumer adoption of online banking platforms, due mainly to its ease of access.

In similar fashion, consumers would be less likely to adopt online banking if and when they perceived it to be inconvenient due to various reasons. For instance, Lee (2008) discovered in his study that certain consumers regarded online banking to be impractical due to delays in processing online payments, or when the waiting time to load a particular service or webpage takes longer than usual. The work of Agarwal, Rastogi, and Mehrotra (2009) also highlighted the importance of transaction speed in online banking, as it is widely cited as one the most common reasons for why consumers choose not to use such platforms. Hence, the hypothesis that can be posited from this is:

H1: There is a positive relationship between convenience and consumer intentions to adopt online banking

\subsection{Trust and Consumer Intention to Adopt Online Banking}

People think about the consequences and implications of their actions before engaging into any specific action or behavior. As earlier mentioned this is one of the core assumptions of TRA and TPB models. According to the models people attitude and subjective norm are the factors that would lead to a trusting or distrusting behavior in adopting a new technology. The following discussion therefore, presents the implications of the empirical work carried out in this respect.

Trust was found to be an important element and significant predictor of adoption for new technologies (Yang, Chandlrees, Lin, \& Chao, 2009; Goles, Lee, Rao, \& Warren, 2009; Holsapple \& Sasidharan, 2005; Chen \& Barnes, 2007). In the context of online banking, trust is defined as the degree to which individuals perceive that usage of this platform is secure and free of privacy threats (Chong et al., 2010). This conception is similar to that of Eriksson, Kerem, and Nilsson (2005), by citing that trust in online banking refers to consumer perceptions regarding the security of 
transactions and privacy protection. In Sathye's (1999) research, the aspects of privacy and security were found to be the most significant impediments to the acceptance of online banking in Australia. Such findings were also prevalent in the studies of Hernandez and Mazzon (2007), Jahangir and Begum (2008), Amin (2007), and Grabner-Krauter, and Faullant (2008), as they too discovered that the individual's trust in the security provided by on the part of the banking platform and the perceived privacy protection when utilizing such outlets are key determinants of consumer intentions to adopt online banking.

Touching on the subject of security, Laforet and Li's (2005) study on the acceptance of online banking in China revealed that the respondents cited this factor to be the most important factor affecting their usage intentions, specifically because they were worried about the threat posed by hackers and online frauds. The work of Poon (2007) also revealed security concerns to hold the strongest influence on consumer intentions to bank online, with respondents citing reasons such as password and login worries, the threat of hackers, and a general distrust of internet and online platforms for financial services. Amongst other security risks were unauthorized account access and network transaction attacks, cited in the study of Maditinos, Chatzoudes, and Sarigiannidis (2013).

Moving on, privacy has often been cited in the literature as well to be one of the factors inhibiting the acceptance of online banking (Eriksson et al., 2005; Howcroft, Hamilton, \& Hewer, 2002; Wisniewski Zougman, Nagaraj, \& Mann, 2009; Yiu, Grant, \& Edgar, 2007; Yousafzai, Pallister, \& Foxall, 2003). The work of Poon (2007) revealed that amongst the reasons for which consumers perceive their personal privacy to be under threat from the use of online banking platforms, includes their doubts about the safe delivery of their personal information and if such information is kept only for the bank provider's usage. The work of Lee (2009) and Subsorn and Limwiriyakul (2012) also produced similar findings, with respondent fearing that their personal information would not be transferred safely or accessed by hackers.

In fact, several authors (Wang \& Barnes, 2007; Wei, Marthandan, Chong, Ooi, \& Arumugam, 2009) who studied the impact of consumer trust as an antecedent of online banking, have recommended bank providers to advertise and campaign to gain consumer trust, or include privacy statements and educate consumers about the security policies and measures in place to encourage higher adoption rates. Yuen, Yeow, and Lim (2014) also stressed the importance for bank providers to communicate to the consumer the collection, dissemination, and storage of their personal information in order to foster a stronger element of trust in the online platform itself. With all that is being said, the next hypothesis that can be postulated is: 
H2: There is a positive relationship between trust and consumer intentions to adopt online banking

\subsection{Perceived Ease of Use and Consumer Intentions to Adopt Online Banking}

Perceived ease of use (PEOU) is one of the constructs derived from the TAM model. Past research has found a significant correlation between the relative ease of use and the adoption of innovation technologies (Venkatesh \& Morris, 2000; Chau \& Lai, 2003; Chang, 2005; Lu, Yu, Liu, \& Yao, 2003; Shih \& Fang, 2004). According to Rogers (2003), the term ease of use refers to the relative complexity of using a new system or technology, which can bear a significant impact on consumer intentions for adoption. In the context of online banking, PEOU is also widely regarded as one of the key determinants of actual adoption (Wang et al., 2003).

For instance, Calisir and Gummusoy (2008) affirmed the construct of PEOU to be a key driver of online banking, with consumers citing that a lower effort expectancy in the usage of such platforms to be more favorable. According to Chong et al. (2010), PEOU in the context of online banking is especially important given that consumers do not have the traditional face-to-face interaction with the provider, which therefore means that the ease of use and user friendliness of the primary or mobile banking site will generate stronger inclinations to adopt such platforms. Gounaris and Koritos (2008) in their modified version of the TAM, also concluded by stating that the PEOU construct remains key to consumer intentions to adopt online banking platform. In other words, the more consumers find the online banking site to be easy to navigate and the execution of normal banking transactions and services to be smooth and free of effort, the more likely it is for them to adopt this channel for future usage (Guriting \& Ndubisi, 2006).

However, there were also studies that revealed mixed results on the effect of PEOU in online banking. For instance, the work of Eriksson et al. (2005) revealed PEOU to be insignificant in explaining consumer intentions to adopt online banking. Such notions were shared by the results of Pikkarainen et al. (2004). Despite that, the majority of the literature in online banking supports the relative strength of the PEOU construct in determining consumer adoption. Hence, the next hypothesis that can be posited is as follows:

H3: There is a positive relationship between perceived ease of use and consumer intentions to adopt online banking 


\subsection{Perceived Usefulness and Consumer Intention to Adopt Online Banking}

In the online banking context, perceived usefulness (PU) is defined as the degree to which consumers perceive that carrying out usual transactions to be more advantageous, efficient, and conducive than the traditional format of visiting a physical branch (Chong et al., 2010).

Past research validates the applicability of the PU construct in predicting technology adoption and system usage. For instance, Jeyaraj, Rottman, and Lacity (2006) found in their extensive review of studies on technology adoption, 26 out of 29 research papers identified the PU construct to be significant. Earlier research in this topic area also substantiate the positive relationship between PU and consumer intentions to adopt online banking (Venkatesh \& Davis, 1996; Agarwal et al., 2000; Chau, 2001; Wang et al., 2003; Pikkarainen et al., 2004; Johnson \& Marakas, 2000). Bhattacherjee (2002) also argued that aside from other factors, the PU construct is one of the critical determinants as to whether an individual would choose to transact with an online firm.

In the study of Pikkarainen et al. (2004) on online banking in Finland, the construct of PU as one of the most significant factors influencing consumer decisions towards adoption. On a similar note, such findings were evident in the work of Gounaris and Koritos (2008) who applied a number of different models, with consumers citing the construct of PU to be one of the key drivers of online banking acceptance. Celik's (2008) web based study in online banking in Turkey also garnered similar results, while the work of Jaruwachirathanakul and Fink (2005) revealed that the more that consumers perceive the online banking platform to be useful, the more likely they are to utilize it. According to several authors (Raman \& Don, 2013; Calisir $\&$ Gummusoy, 2008), one the key utilities that consumers seek in an online banking platform is its expediency and practicality, which also means that platforms that could possibly enhance the productivity of the individual in carrying out transactions will be more desirable. The opposite is also true, as malfunctions and breakdowns are likely to discourage and inhibit the adoption of online banking platforms as noted by Littler and Melanthiou (2006) and Featherman and Pavlou (2003). Hence, in light of the evidence provided in the literature, the next hypothesis that can be posited is:

H4: There is a positive relationship between perceived usefulness and consumer intentions to adopt online banking

\subsection{Social Influence and Consumer Intention to Adopt Online Banking}

Based on evidence in the literature, one of the less explored factors that might 
possibly possess a significant impact on consumer intentions to adopt online banking is that of social influence. According to Marr and Prendergast (1993), the lack of human interaction can significantly inhibit the adoption of new technologies. Such views are shared by Venkatesh and Morris (2000), who opined that social influence is an important determinant of new technology adoption from a perspective of awareness raised from the feedback of friends and family.

Social influence, in this context consequently refers to the influence of the individual's friends, family, colleagues, and anyone within their social circle that possess the ability to alter their intentions towards usage of online banking platforms (Taylor \& Todd, 1995; Tan \& Teo, 2000; Yang et al., 2009). According to Forsythe and Shi (2003), negative perceptions from the social circle of the individual can inhibit his/ her intention to engage in online banking. The work of Kim et al. (2009) supports this, by saying that positive recommendations from friends and families can actually encourage the uptake of online banking services. Meanwhile, Jin, Park, and Kim (2008) also discovered in their study that consumers from a collectivistic background are more likely to seek advice from their peers and social others before accepting a technology. Therefore, the next hypothesis postulated based on these studies is:

H5: There is a positive relationship between social influence and consumer intentions to adopt online banking

\subsection{Gender and Their Intention in Adopting Online Banking}

In past studies, males and females were found to vary significantly in their intentions to adopt different banking channels, especially that of online banking (Sathye, 1999; Karjaluoto, Mattila, \& Pento, 2002; Al-Ashban \& Burney, 2001). However, the findings are largely mixed and inconclusive.

For instance, the study of Flavia'n (2006) reported that females were less likely to perform banking transactions online compared to their male counterparts. Similar findings were observed in the work of Singh (2004) and Akinci, Aksoy, and Atilgan (2004). Additionally, the work of Srivastava (2007) also revealed that gender differences in the adoption of online banking to be significant, with men being the more likely group to utilize this platform given their relative familiarity with the internet and technology in general. Munusamy (2012) also argued that males are more likely to adopt online banking platforms, substantiated by the statistics of MCMC (2008) that revealed 51.9 of individuals who performed banking transactions from home to be males.

However, the study of Poon (2007) contradicts such notions, as it was revealed that there were no significant differences between men and women in terms of their 
acceptance of online banking. Clemes, Gan, and Du (2012) discovered dissimilar findings by reporting women to be more likely users of online banking. Lichtenstein and Williamson (2006) also found females to the more frequent users of online banking in their study, capitalizing on the utility of the platform due their busy lives of raising children and managing their households. Hence, it is more often than not that gender differences are significant with regards to their intentions to bank online as supported by the literature. Only a few instances recorded the intentions between men and women to use this platform to be statistically insignificant. With that in mind, the hypothesis that can be drawn is:

H6: Gender differences affect their intentions in adopting online banking

\subsection{Age Groups and their Intentions in Adopting Online Banking}

According to Rogers (2003), younger consumers are more reactive to new technologies. Such notions were also reflected in Poon's (2007) study, which revealed younger consumers to be more open to using online banking because they are more familiar with the internet. Alagheband (2006) also asserted that individuals who adopt online banking were more likely to be consumers of the younger age group, which is parallel to the findings of Karjalujotoet et al. (2002).

According to Howcroft et al. (2002), such trends hold true possibly because younger consumers are less bothered about the lack of face-to-face contact inherent in online banking platforms as compared to their older counterparts. This argument seems to be supported by the work of Jaruwachirathanakul and Fink (2005), as the authors opined that older consumers generally hold negative attitudes about online banking because they cannot see the advantages of using such a platform. In fact, most studies in the literature also identified a negative relationship between age and consumer intentions to bank online across various cultural environments and countries (Polatoglu, \& Ekin, 2001; Kerem, 2002; Waite \& Harrison, 2004; Wilson, 2000; Joseph \& Stone, 2003). Therefore, the following hypothesis is made:

H7: There are significant differences between younger and older consumers in their intentions to adopt online banking

Having conducted an extensive review of the literature and incorporated various factors into the present study, the conceptual model is constructed as follows:

\section{Methodology}

This section is mainly concerned with discussing the various measurement methodologies used in this research. Firstly, the discussion begins with defining the setting 


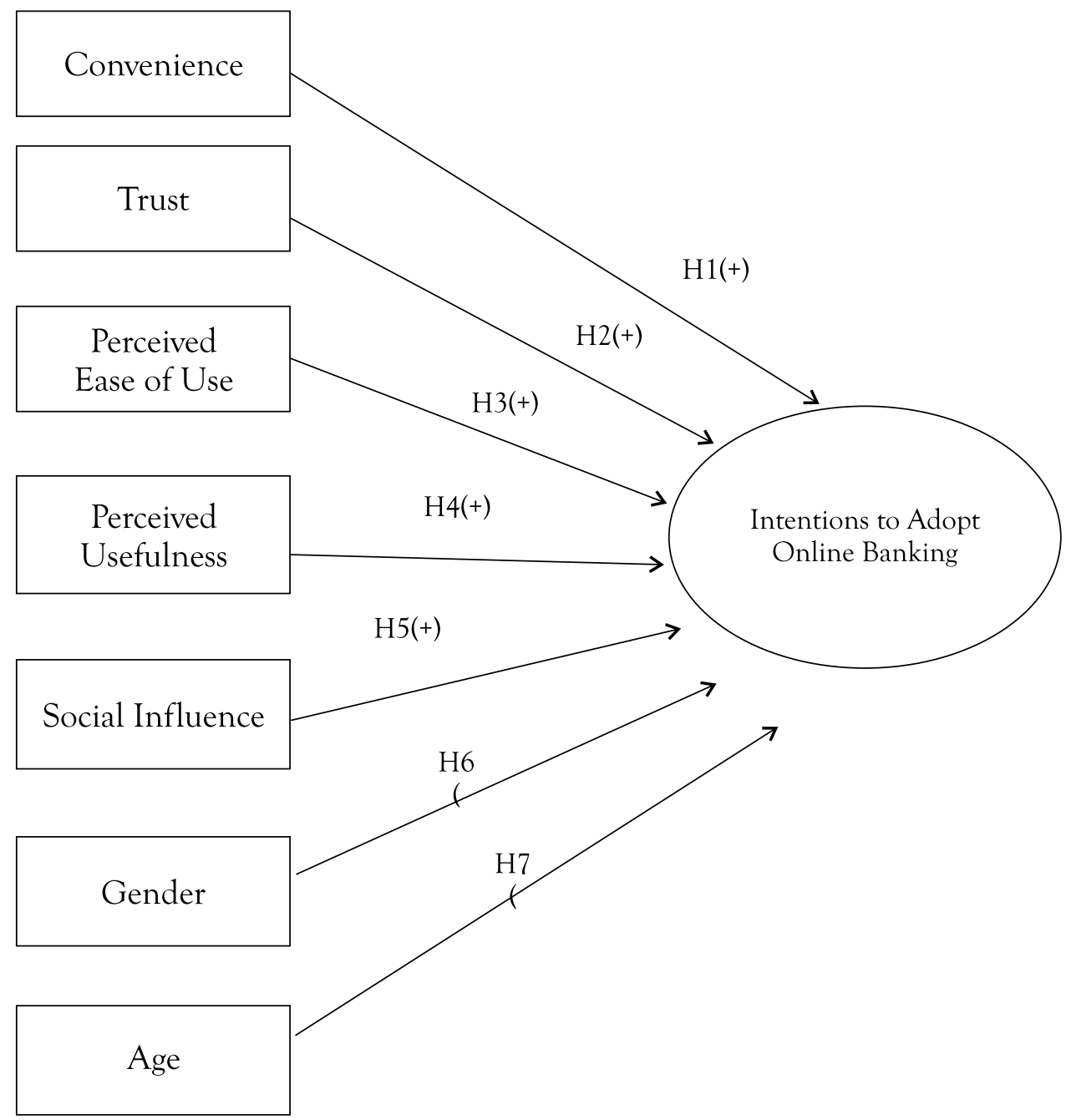

Figure 2: The Conceptual Model

of the study, and the participants targeted for the responses, afterwards a detailed explanation of the sampling plan, followed by an outlining of the data collection process and research instrumentation. Last but not least, a brief elaboration of the details and methods used for data analysis will also be provided.

As with most research, choosing the setting of the study is often one of the most important decisions. The decision to choose a wrong setting may result in measurement inconsistencies, and as such due caution needs to be exercised before making the final choice. While the study is on factors affecting consumer intentions to adopt online banking, a mere study of such motives over the internet may not be the best representation since it is impossible to tell if these consumers are exposed and knowl- 
edgeable enough to judge their prior experiences. Additionally, while conducting this study within the premises of a bank would be highly desired, it is likely to be met with restrictions. Hence, the next best alternative is to conduct this study in the nearby premises of the bank, where respondents can be approached upon their exit from the bank, after they have completed their respective transactions and errands.

To do this successfully, two specific areas with high concentration of local and international bank branches were selected. These areas are SS15 and USJ10 in Subang Jaya. Amongst the banks that can be located across these areas include CIMB Bank, Maybank, RHB Bank, Standard-Chartered, Citibank, AmBank, Affin Bank, Bank Simpanan Nasional, Bank Raykat, Public Bank, Hong Leong Bank, and HSBC.

Another important consideration is the participants to be chosen for this research. To qualify as participants for this study, individuals need to fulfill a specific criterion. Although it is not the most rigid criterion, it is deemed to be absolutely necessary in this context for the individuals to be 18 years of age or above. In other words, those who do not meet this criterion will have their responses omitted in the later sections. The rationale in setting this condition was based on the argument of Clemes, Brush, and Collins (2011) of how individuals below the age of 18 may have difficulties interpreting the requirements of the questionnaire, and hence possibly contribute to irrelevant findings in that context. Furthermore, individuals below 18 years of age are unlikely to transact actively with a bank because they are still under the care of their parents, and the products that they have with the bank such as debit and credit cards are usually a supplementary one provided by their parents. Beyond that, there are no other restrictions for the individuals to participate in the study.

Moving on, the next step is to deliberate the sampling plan to be used for this study. The sampling plan involves two major components, namely the sample size and sampling technique to be used. Before deciding the sample size, it must be noted that there are budget and time limitations in the current research, especially because it is cross-sectional. With that being said, the complexities present in this context explain the need for sampling. Whilst a sample may not be entirely representative of the total population, there are no studies to date to actually prove that it is any less valid to use a sample (Saunders, Lewis, \& Thronhill, 2012). In fact, there were instances where a sample produced results with higher precision compared to the total population as highlighted by Henry (1990) in his stud. Referring to past studies in online banking (Yuen et al., 2014; Ndubisi \& Sinti, 2006; Poon, 2007; Chong et al., 2010), the number of responses gathered were usually between the range of 100 to 300 responses. Hence, the current study aims to take a middle point between these 2 figures, with the sample size set at 200 responses. Additionally, since this study attempts to understand if there are any differences in consumer intentions to adopt 
online banking between men and women, the quota sampling technique was used. Quota sampling means that the number of males and females participating in this study were controlled, and they were equal at all times to ensure that neither group is overrepresented or underrepresented. This step is expected to yield the most accurate results, especially where the measure of gender differences is concerned.

Next in the discussion is the data collection process. For this research, a face to face survey method was employed. Self-administered questionnaires were used in an intercept approach towards individuals leaving the premises of their respective banks after their intended transactions have been completed. The individuals will be briefed on the instructions, and then asked to fill up the questionnaire accordingly after they have provided their consent and agreement to participate in this research. As there are two separate locations used as the setting, the data collection process in each area will take specific turns in a rotational method. Data will first be collected between the hours of 10am-1130am on weekdays, and 10am-1130am and $230 \mathrm{pm}-4 \mathrm{pm}$ on weekends in the USJ10 area. The following week is where the data collection process with the same timeslots will be moved to the SS15 area. The timeslots were decided accordingly so as to not clash with peak hours where individuals would be unlikely to participate as they need to get on with their activities. The data collection process is anticipated to take a period of 2 weeks to 1 month, and will be continued until the targeted sample size of 200 is obtained.

Self-administered questionnaires were used in the current study. These questionnaires contained 3 separate sections. The first section is where a cover page is provided, accompanied by the basic information of the study and its background details.

The second section is where individuals were required to provide their answers to a list of 29 statements under the constructs of perceived usefulness, perceived ease of use, trust, convenience, social influence, and intentions to adopt online banking. They respondents will need to state the extent of their agreement or disagreement with each statement via a 5-point Likert scale. A response of "1" means that they "Strongly Disagree", "2" meaning that they "Disagree", "3" meaning that they are "Neutral", "4" meaning that they "Agree", and " 5 " meaning that they "Strongly Agree". Additionally, it is noteworthy to mention that the statements listed under each construct were adapted from various sources and past studies. Table 1 provides a better illustration of the sources for each construct:

A number of different analysis will be carried out in this study after the 200 responses have been collected, using the software SPSS 20. Firstly, a Cronbach's alpha analysis will be performed to provide better clarity on whether the questionnaire and the items encapsulated within possess internal consistency and reliability. Any items that do not meet the minimum cut-off rate for rejection will be removed from the 
Table 1: Summary of Constructs

\begin{tabular}{|c|c|c|}
\hline Measure & Number of Items & Source \\
\hline Convenience & 5 & Poon (2007) \\
\hline Trust & 5 & Chong et al. (2010) \\
\hline Perceived Ease of Use & 5 & Gounaris and Koritos (2008) \\
\hline Perceived Usefulness & 5 & Chong et al. (2010) \\
\hline Social Influence & 4 & Laforet and Li (2005) \\
\hline Intentions to Adopt Online Banking & 5 & Chong et al. (2010); Poon (2007) \\
\hline
\end{tabular}

questionnaire.

Following that, a correlation analysis will be performed to provide a preliminary idea of the interrelationships between all variables, and to confirm if there are any instances of multicollinearity in the current model. After that, a multiple linear regression analysis will then be executed to confirm the which of the factors of convenience, trust, perceived ease of use, perceived usefulness, and social influence affect consumer intentions to adopt online banking, and to what extent.

Next, an independent samples t-test will also be carried out to identify if there are any significant differences in the intentions to adopt online banking between men and women. Last but not least, a one-way ANOVA will similarly be performed to see if there are any of these differences between varying age groups.

\section{Results \& Discussion}

There were a total of 200 responses collected in this study, but only 190 of these responses were used for the data analysis and reporting section because 10 responses contained missing data and incomplete information. With the 190 remaining responses, a descriptive analysis was first performed to provide a brief identity of the participants in this study. Firstly, it is noted that there were slightly more male participants compared to female participants in this study. Despite the use of quota sampling to ensure that neither of these groups are over or underrepresented, the missing data collected from 8 female participants and 2 male participants threw the number off slightly. With that being said, this means that there were 98 male participants (51.6\%) and 92 female participants (48.4\%) from the pool of 190 usable responses. In addition to that, the age of the participants was also captured in this study. Majority of the responses were gathered from participants in 34 to 41 years' age group with 60 participants (31.6\%), followed by 56 participants who were aged between 26 to 33 years (29.5\%), 29 participants who were aged between 42 to 49 years (15.3\%), 23 participants who were aged 50 years and above (12.1\%), and 22 
Table 2: Participant Profile Summary

\begin{tabular}{|c|c|c|c|c|}
\hline Description & Option & Frequency & Percentage (\%) & $\begin{array}{c}\text { Cumulative } \\
\text { Percentage (\%) }\end{array}$ \\
\hline Participants & & 190 & & \\
\hline Gender & Male & 98 & 51.6 & 51.6 \\
\hline & Female & 92 & 48.4 & 100.0 \\
\hline Age & $18-25$ years & 22 & 11.6 & 11.6 \\
\hline & $26-33$ years & 56 & 29.5 & 41.1 \\
\hline & $34-41$ years & 60 & 31.6 & 72.6 \\
\hline & $42-49$ years & 29 & 15.3 & 87.9 \\
\hline & $\begin{array}{c}50 \text { years and } \\
\text { above }\end{array}$ & 23 & 12.1 & 100.0 \\
\hline
\end{tabular}

participants who were aged between 18 to 25 years $(11.6 \%)$. The results in Table 2 summarize these details.

Next, a reliability analysis was taken to confirm the presence of internal reliability and consistency between the multiple scale measurements in a construct. According to DeVellis (1991), the Cronbach's alpha coefficient should be higher than 0.7 as any value below that figure is suspected to be unreliable and therefore unacceptable.

Table 3: Cronbach's Reliability Summary

\begin{tabular}{|c|c|c|}
\hline Construct & Cronbach's Alpha & Number of Items \\
\hline Convenience (CVE) & 0.843 & 5 \\
\hline Trust (TRU) & 0.857 & 5 \\
\hline Perceived Ease of Use (PEOU) & 0.871 & 5 \\
\hline Perceived Usefulness (PU) & 0.775 & 4 \\
\hline Social Influence (SI) & 0.858 & 5 \\
\hline Online Banking Intentions (OBK) & 0.745 & 5 \\
\hline
\end{tabular}

Malhothra (2003) meanwhile suggested that the cut-off rate for rejection of a construct should be 0.6. To confirm if the constructs used in this study satisfied both arguments, a closer look is taken at the results in Table 3.

As seen above, each of the 6 constructs of convenience $(\alpha=0.843)$, trust $(\alpha=$ $0.857)$, perceived ease of use $(\alpha=0.871)$, perceived usefulness $(\alpha=0.775)$, social influence $(\alpha=0.858)$, and online banking intentions $(\alpha=0.745)$ recorded alpha scores above the minimum required limit. Hence, it is concluded that internal consistency 
is present in this context between the measurements of the different variables.

Consequently, a correlation test was also carried out to investigate the relationship and strengths between the independent factors towards the dependent factor in this study. As Evans (1996) argued, a weak correlation is present when the correlation coefficient between an independent variable and dependent variable is between 0.01 to 0.39 , whereas a strong correlation is present when the r-value is between 0.60 to 0.99 and an r-value between 0.40 to 0.59 depicts a moderate correlation.

Referring to the results in Table 4, it is noted that trust $(r=0.698)$, perceived ease of use $(r=0.712)$, and perceived usefulness $(r=0.688)$ is strongly correlated to

Table 4: Pearson's Correlation Summary

\begin{tabular}{|c|c|c|c|c|c|c|}
\hline Construct & CVE & TRU & PEOU & PU & SI & OBK \\
\hline Convenience (CVE) & 1 & -0.039 & -0.013 & 0.124 & -0.001 & 0.125 \\
\hline Trust (TRU) & -0.039 & 1 & $0.666^{* *}$ & $0.570^{* *}$ & $0.516^{* *}$ & $0.698^{* *}$ \\
\hline $\begin{array}{c}\text { Perceived Ease of Use } \\
\text { (PEOU) }\end{array}$ & -0.013 & $0.666^{* *}$ & 1 & $0.733^{* *}$ & $0.586^{* *}$ & $0.712^{* *}$ \\
\hline $\begin{array}{c}\text { Perceived Usefulness } \\
\text { (PU) }\end{array}$ & 0.124 & $0.570^{* *}$ & $0.733^{* *}$ & 1 & $0.573^{* *}$ & $0.688^{* *}$ \\
\hline \begin{tabular}{c} 
Social Influence (SI) \\
\hline $\begin{array}{c}\text { Online Banking } \\
\text { Intentions (OBK) }\end{array}$
\end{tabular} & -0.001 & $0.516^{* *}$ & $0.586^{* *}$ & $0.573^{* *}$ & 1 & $0.562^{* *}$ \\
\hline
\end{tabular}

consumer intentions to adopt online banking. Meanwhile, the results also suggest that a moderate correlation is present between social influence $(r=0.562)$ and online banking intentions, whereas the factor of convenience $(r=0.125)$ is weakly correlated to the dependent measure.

In addition to that, it is confirmed that there is no problem of multicollinearity in this model, and hence no redundant information was contributed to the same model. Multicollinearity exists when the R-values between two independent factors are 0.80 or higher (Garson, 2011), which is non-existent in this context. To further validate the significance of the independent factors in explaining online banking intentions, a multiple linear regression analysis was undertaken.

Referring to the results in Table 5, it is clear that the p-value of the regression 
Table 5: Results of the Multiple Linear Regression Model

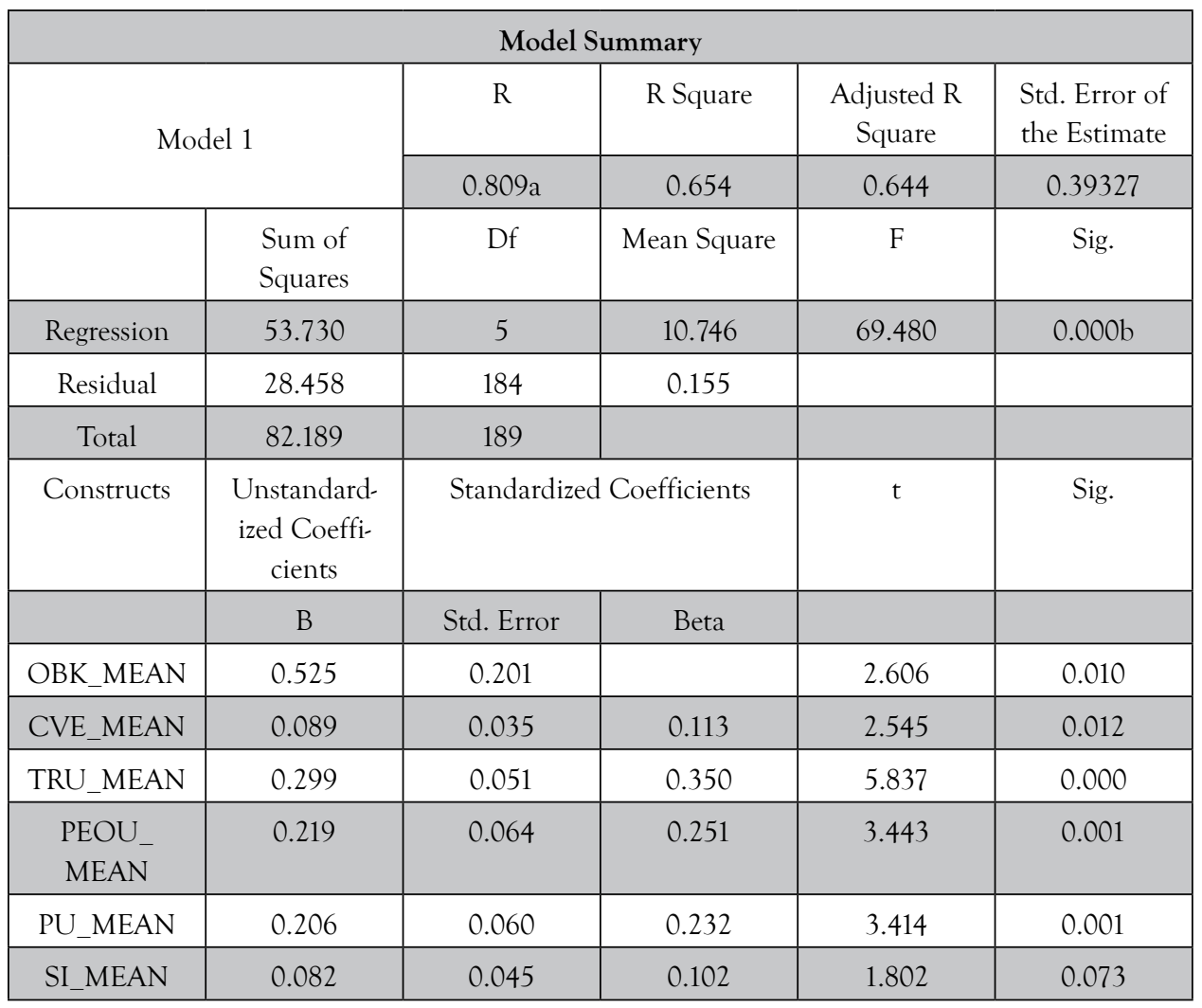

model is $\mathbf{0 . 0 0 0}$. This means that at least one of the 5 independent factors identified in this study is significant in explaining the dependent measure, as the p-value is below 0.05 (Field, 2005).

Beyond that, the results suggest that the factors of convenience $(\mathrm{p}=0.012 ; \mathrm{t}=$ $2.545 ; b=0.089)$, trust $(p=0.000 ; t=5.837 ; b=0.299)$, perceived ease of use $(p=$ $0.001 ; t=3.443 ; b=0.219)$, and perceived usefulness $(p=0.001 ; t=3.414 ; b=0.206)$ possess a significant influence on online banking intentions, as indicated by their p-values and t-values that are below 0.05 and above 2.00 respectively. In addition to that, the beta values of these 4 factors also suggests that their relationship with the dependent variable is positive. These results from the analysis support and substantiates the empirical work of Agarwal et al. (2009), Subsorn and Limwiriyakul (2012), Calisir and Gummusoy (2008), and Gounaris and Koritos (2008) where the studies showed the same results from their analysis.

However, the results do not support the empirical work of Jin et al. (2008) and Kim et al. (2009) which suggested that social influence plays significant role in the 
adoption or non-adoption of online banking. Social influence $(\mathrm{p}=0.073 ; \mathrm{t}=1.802 ; \mathrm{b}$ $=0.082)$ was proven to be statistically insignificant in explaining consumer intentions to adopt online banking in this study. With the adjusted r-square of 0.644 as sighted above, this means that the $64.4 \%$ of the variation in consumer intentions to adopt online banking can be explained by the variation in convenience, trust, perceived ease of use, and perceived usefulness. The overall regression model is also deemed to be a good fit.

Table 6: Independent Sample t-test Results

\begin{tabular}{|c|c|c|c|c|c|c|}
\hline $\begin{array}{l}\text { Group Sta- } \\
\text { tistics }\end{array}$ & GEN & $\mathbf{N}$ & Mean & \multicolumn{2}{|c|}{ Std. Deviation } & $\begin{array}{c}\text { Std. Error } \\
\text { Mean }\end{array}$ \\
\hline \multirow{2}{*}{$\begin{array}{l}\text { Online Bank- } \\
\text { ing Intentions } \\
\quad(\mathrm{OBK})\end{array}$} & Male & 98 & 3.7837 & \multicolumn{2}{|c|}{0.73030} & 0.07377 \\
\hline & Female & 92 & 3.9087 & \multicolumn{2}{|c|}{0.57142} & 0.05957 \\
\hline \multirow{2}{*}{$\begin{array}{c}\text { Levene's Test } \\
\text { for Equality of } \\
\text { Variances }\end{array}$} & \multicolumn{6}{|c|}{ t-test for Equality of Means } \\
\hline & $\mathrm{F}$ & Sig. & $\mathrm{t}$ & $\mathrm{df}$ & Mean Difference & $\begin{array}{l}\text { Std. Error } \\
\text { Difference }\end{array}$ \\
\hline $\begin{array}{c}\text { Equal varianc- } \\
\text { es assumed }\end{array}$ & 1.478 & 0.226 & -1.308 & 188 & 0.192 & -0.12502 \\
\hline $\begin{array}{c}\text { Equal } \\
\text { variances not } \\
\text { assumed }\end{array}$ & & & -1.318 & 182.181 & 0.189 & -0.12502 \\
\hline
\end{tabular}

An independent samples t-test analysis was correspondingly performed to confirm if there are any significant differences in online banking intentions between males and females as previously suspected. The results are shown in Table 6 .

As far as the results from $\mathrm{H} 6$ are concerned, the data analysis is in contradiction with the empirical work from Srivastava (2007) and support the work from Poon (2007). Referring to the results, it is evident that the p-value of the model is 0.226 . Since this figure is above 0.05 , equal variances are assumed in this context. In other words, there are no significant differences in online banking intentions between males and females in this study. The respective mean scores of males $(\mathrm{m}=3.7837)$ and females (3.9087) would also confirm such notions as the differences are very minimal.

Last but not least, a one-way ANOVA analysis was undertaken to confirm if there are any significant differences in online banking intentions between different age groups. The results of the one-way ANOVA are presented in Table 7:

As seen above, the p-value of this one-way ANOVA model is 0.444 , which is also 


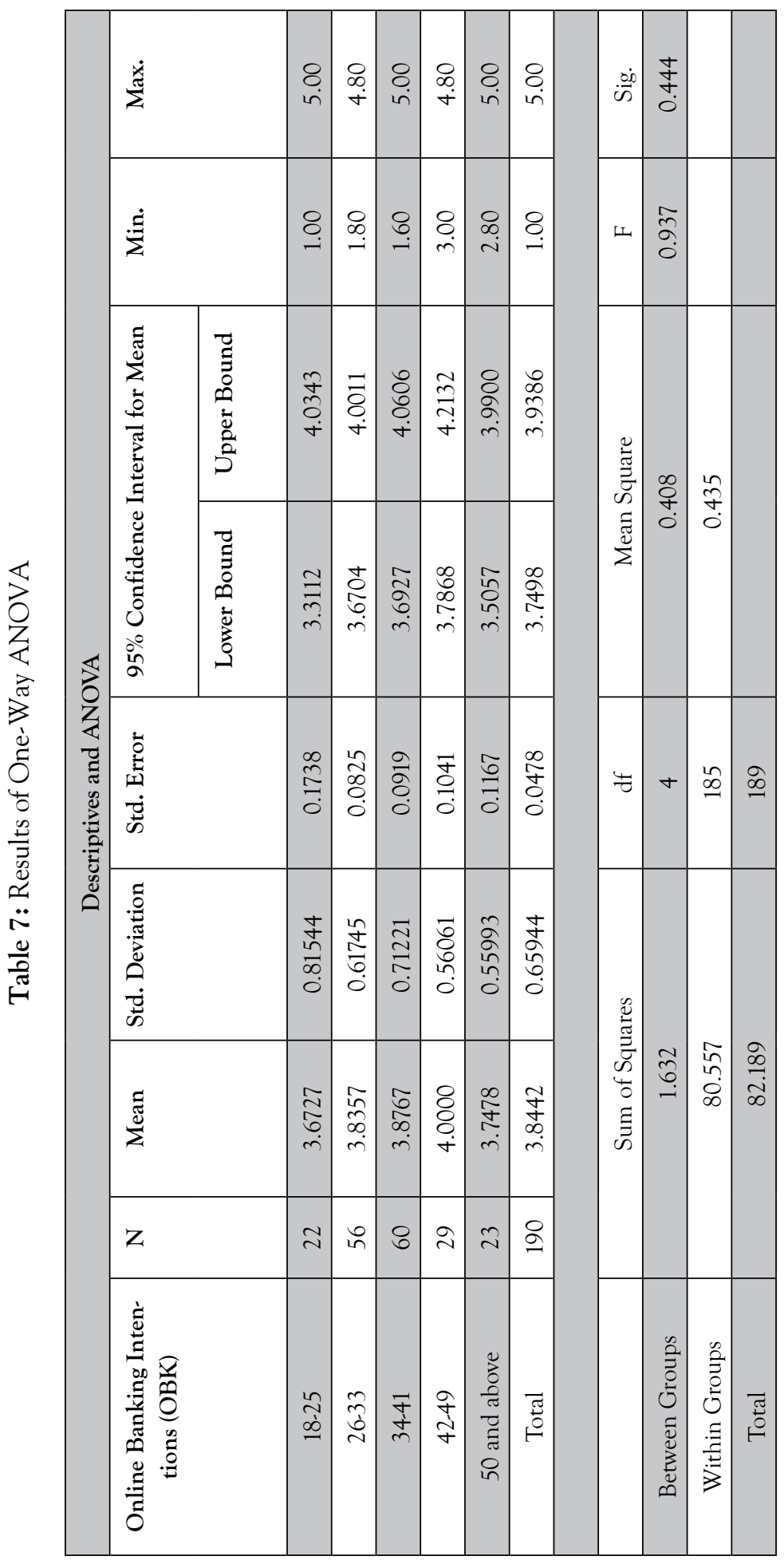


higher than 0.05 . Therefore, it is also confirmed that there are no significant differences in intentions to adopt online banking between different age groups. The mean scores of each of the respective groups of participants who were aged between 18 to 25 years $(\mathrm{m}=3.6727), 26$ to 33 years $(\mathrm{m}=3.8357), 34$ to 41 years $(\mathrm{m}=3.8767), 42$ to 49 years $(\mathrm{m}=4.0000)$, and 50 years and above $(\mathrm{m}=3.8442)$ also provides further clarification to such reported findings, as the differences in the scores recorded were relatively minimal between the 5 different age groups. This study was conducted with the specific motive on understanding and investigating the factors that are affecting consumer intentions to adopt online banking in the context of Malaysia. For this purpose, three research questions were posed in the study.

To address the first research question, a correlation test and multiple regression analysis was utilized. From the results of the joint analysis as reported in the earlier subsections, it was suggested that there were 4 antecedents of intentions to adopt online banking identified in this study.

One of these factors that was found to be significant in explaining consumer intentions to adopt online banking is that of convenience $(\mathrm{p}=0.012 ; \mathrm{b}=0.089 ; \mathrm{r}$ $=0.125$ ). Firstly, it is noticeable that while the results of the correlation test suggest that convenience is weakly correlated to online banking intentions, the results of the regression analysis maintains that it is still significant in predicting the dependent measure, and the relationship is positive. This means that the more that consumers think that online banking offers them a convenient way to solve their banking needs compared to the traditional format, the more likely they are to actually transact over such online platforms. The hypothesis $\mathrm{H}_{1}$ is therefore accepted. These findings are also similar to those identified in the literature (Polatoglu \& Ekin, 2001; Rotchanakitumnuai \& Speece, 2003; Raman \& Don, 2013; Poon, 2007; Lee, 2008; Agarwal et al., 2009) in confirming the positive relation between convenience and consumer intentions to adopt online banking.

The next factor that was identified to have a significant influence towards online banking intentions is that of trust $(p=0.000 ; b=0.299 ; r=0.698)$. The correlation results suggest that a strong correlation is present between these two variables, whereas the regression results confirm that trust was the most significant predictor of online banking intentions in this study. In other words, the more that customers trust the platform and the online services provided by their respective banks, the more likely they are to conduct transactions via the internet. Therefore, the hypothesis $\mathrm{H}_{2}$ is also accepted. The findings on trust is this context is consistent with the work of other researchers (Wang \& Barnes, 2007; Wei et al., 2009; Yuen et al., 2014; Lee, 2009; Subsorn \& Limwiriyakul, 2012) who also sought to understand its impact on consumer intentions to adopt online banking. 
Moving on, another factor that has been confirmed to be significant in predicting consumer intentions to adopt online banking is perceived ease of use $(p=0.001 ; b=$ $0.219 ; \mathrm{r}=0.712$ ). The results derived from the joint analysis also suggest that there is a positive relationship between perceived ease of use and online banking intentions. In other words, this means that the more that consumers believe that performing banking transactions online are easy and free of effort, they more likely they are to actually use it. With that being said, it means that the hypothesis $\mathrm{H}_{3}$ is also accepted. In light of the current context, these findings were similarly substantiated by the results observed in previous studies (Calisir \& Gummusoy, 2008; Chong et al., 2010; Gounaris \& Koritos, 2008; Guriting \& Ndubisi, 2006; Eriksson et al., 2005; Pikkarainen et al., 2004) documenting the impact of perceived ease of use on online banking.

Last but not least, the factor of perceived usefulness $(\mathrm{p}=0.001 ; \mathrm{b}=0.206 ; \mathrm{r}=$ 0.688) also showed a significant interaction with online banking intentions. As the results would suggest, the relationship between perceived usefulness and intentions to adopt online banking is also positive. In line with that, this indicates that the more consumers think that performing banking transactions via mobile or the internet is more efficient and improves their expectancies, the more likely they are to actually adopt it and utilize on a regular basis. The hypothesis $\mathrm{H}_{4}$ is also accepted. Previous studies in the online banking context (Celik, 2008; Jaruwachirathanakul \& Fink, 2005; Littler \& Melanthiou, 2006; Featherman \& Pavlou, 2003; Pikkarainen et al., 2004) would also validate such findings in providing affirmation for the notion of perceived usefulness having a positive effect towards online banking intentions.

However, it was noticed in the current study that social influence $(\mathrm{p}=0.073 ; \mathrm{b}$ $=0.082 ; \mathrm{r}=0.562$ ) had no impact towards online banking intentions. Although the results of the correlation test suggested that the relationship between these 2 variables are moderate, the multiple linear regression test confirms that social influence was statistically insignificant in explaining consumer intentions to adopt online banking. As such, the hypothesis $\mathrm{H}_{5}$ is rejected. The findings in the current study does not align with those identified in the earlier work of other scholars in the similar field (Forsythe \& Shi, 2003; Jin et al., 2008; Tan \& Teo, 2000; Yang et al., 2005).

Beyond that, the independent samples t-test conducted to answer the second research question also shows that there are no significant differences in online banking intentions between males and females $(p=0.226)$, at least in the context of this study. The mean scores of both respective groups are relatively similar, and any differences that were sighted are assumed to be minimal. In other words, males and females are equally as likely and inclined, or equally unlikely to adopt online banking in the current context. Hence, the hypothesis $\mathrm{H}_{6}$ is rightfully rejected. These findings contradict the work of several studies (Lichtenstein $\&$ Williamson, 2006; 
Clemes, Gan, \& Du, 2012), but is consistent with the research of Poon (2007) who also discovered that there were no significant differences between men and women towards online banking.

Similarly, a one-way ANOVA test was undertaken to identify if there are any significant differences in online banking intentions between consumers of different age groups, in line with the third research question. The results of the ANOVA test however proved that such differences were also absent in the current study $(p=0.444)$. In other words, this means that consumers of the 5 different age groups identified in this research are equally likely to adopt online banking, and the notion that younger consumers may be more in favor of such platforms as compared to their older counterparts as hypothesized earlier is unsupported. Therefore, the hypothesis $\mathrm{H}_{7}$ is also rejected. Such findings would seemingly vary in contrast to the trends noted in previous studies (Polatoglu et al., 2001; Kerem, 2002; Waite \& Harrison, 2004; Wilson, 2000; Joseph \& Stone, 2003) documenting the age effect towards online banking.

From the results highlighted earlier, 'trust' is confirmed to be the most important predictor of online banking intentions in the current research. The findings imply that trust remains as one of the major concerns consumers have towards conducting financial transactions online, in fear of possibly incurring undesired and unexpected monetary losses. With that in mind, it is therefore highly critical for marketers and banking operators to instill the element of trust into their respective offerings to encourage consumer uptake. One of the ways for which such actions can be outlined is to continually invest in data protection and encryption software, as well as reminding consumers of the steps that have been taken to ensure their security online. Besides that, measures could also be taken to educate customers about the various forms of online scams and frauds, so as to guarantee that there is an additional layer of protection towards such problems.

Additionally, 'perceived ease of use' was also shows a positive and significant impact towards online banking intentions. These findings suggest that customers also allocate a high importance to the relative complexity of the online banking system before actually wanting to use it. Such notions present a number of important implications for the online banking operators. In order to attract a larger pool of new customers, and to prevent the existing users from lapsing, banking operators need to work closely with system integrators and software developers to ensure that their respective online platforms are designed in such a way that enables customers to perform their transactions without hassle and stress. Another initiative that would alleviate such concerns is to provide proper tutorials, instructions, and even communicative adverts across different mediums to educate customers on how to use online banking systems appropriately. 
Another factor that was identified to be significant in predicting online banking intentions in the current context is that of 'perceived usefulness'. In other words, one of the many considerations that consumers take into account when it comes to online banking is the degree to which using the system would help them accomplish the same activity more effectively and efficiently as compared to having to do it within a physical branch of the banking unit. To ensure that this is always the case, banking operators need to ensure that their online banking platforms and applications are always maintained regularly so that there are no malfunctions and interruptions, especially during peak hours. Besides that, the online platform should also be designed in such a way where offers consumers certain benefits in comparison to banking the traditional way, such as the increased speed of financial transfers and the easier tracking of personal accounts.

Lastly, the factor of 'convenience' is also significant in explaining consumer online banking intentions. This means that part of the consideration to use online banking systems is the perceptions of customers towards the ease of banking from anywhere and at any time, without the hassle of visiting a physical branch to perform administrative transactions. Since this a personal characteristic and perception that consumers hold, online banking operators need to continually reiterate the convenience and time savings that consumers enjoy in using online banking systems. This would include specific marketing messages to help consumers understand how online banking is more convenient and practical in certain situations.

\section{Conclusion}

The study utilized two basic models for analyzing the phenomena under investigation i.e. the TRA and TPB models. Three research questions were developed for this purpose, where the first research question was to address the factors that influence the consumer intention in adopting online banking. The second and third research questions were to address the gender and age group effects on the consumer intentions in adopting online banking. A total of seven factors were identified to have an effect on consumer intention in adopting online banking and those were convenience, trust, perceived ease of use, perceived usefulness, social influence, gender and age groups. The first four factors were found to have significant effects whereas the last three factors had no significant effect on consumer intention in adopting online banking.

With the factors that were identified to be insignificant in this study, there might possibly be several explanations for the results observed. Firstly, one of the reasons for which social influence appeared to be insignificant due to the large representation of older respondents in this study. According to Steinberg and Monahan (2007) who studied the resistance to social influence by means of age, it was adolescents and 
younger adults who are known to be more susceptible to social influence in their general behaviors. Older adults were generally quite independent in terms of their decision making, and do not always rely on the opinions of the people in their social circle when making important choices. Such conceptions could possibly explain the rationale as to why social influence was insignificant in this context, since older consumers accounted for over $89 \%$ of the total respondents who participated. As for the findings on gender and age, one of the possible reasons that contribute to such insights is due to the changing consumer landscape within the nation. Malaysia has often been sounded out as one of the countries with high internet and smartphone penetration, which could explain why the use of online banking does not differ much by virtue of age and gender Malaysians in general are very comfortable with the use of a technology.

The current study contributes positively to the literature in demonstrating that a large variety of factors could have an impact on consumer decisions to adopt online banking systems. Such insights and findings would help banking operators and marketers manage their respective portfolio of clients better and be more aware of the potential loopholes and key success factors that are inherent of the system in maintaining a competitive stance in the market. Despite that, this study is not a perfect representation of all the factors that could explain online banking adoption by any means, which hence raises the need for more research in this topic area to help the use of this platform grow even further.

Besides that, future studies could also opt to look into the specific offerings covered within an online banking platform. This is because online banking contains many extensions, such as fund transfer, currency exchange, payment transaction, unit trust investments and so forth. As a general idea, future researchers could go on step further to identify if the factors affecting the use of each individual product is similar or different.

\section{References}

Abu, S. E., \& Pearson, J. M. (2007). Internet banking in Jordan: The unified theory of acceptance and use of technology (UTAUT) perspective. Journal of Systems and Information Technology, 9(1), 78-97.

Adams, D., Nelson, R. R., \& Todd, P. (1992). Perceived usefulness, ease of use, and usage of information technology: A replication. MIS Quarterly, 16(2), 227-48.

Agarwal, R., Rastogi, S., \& Mehrotra, A. (2009). Customers' perspectives regarding e-banking in an emerging economy. Journal of Retailing and Consumer Services, 16, 340-351.

Agarwal, R., Sambamurthy, V., \& Stair, R. M. (2000). Research report: The evolving relationship between general and specific computer self-efficacy: An empirical assessment. Information Systems 
Research, 11(4), 418-30.

Ajzen, I. (1991). The theory of planned behaviour. Organisational Behaviour and Human Decision Processes, 50, 179-211.

Akinci, S., Aksoy, S., \& Atilgan, E. (2004). "Adoption of internet banking among sophisticated consumer segments in an advanced developing country”. International Journal of Bank Marketing, 22(3), 212-32.

Alagheband, P. (2006). "Adoption of e-banking services by Iranian customers". Unpublished Master Thesis. Lulea University of Technology.

Al-Ashban, A. A., \& Burney, M. A. (2001). Customer adoption of tele-banking technology: The case of Saudi Arabia. International Journal of Bank Marketing, 19(5), 191-200.

Alegre, J., \& Cladera, M. (2009). Analysing the effect of satisfaction and previous visits on tourist intentions to return. European Journal of Marketing, 43(5/6), 670-685.

Al-Hawari, M., \& Ward, T. (2006). The effect of automated service quality on Australian banks' financial performance and the mediating role of customer satisfaction. Marketing Intelligence $\mathcal{E}$ Planning, 24(2), 127-147.

Amin, H. (2007). Internet banking adoption among young intellectuals. Journal of Internet Banking and Commerce, 12(3), 01-05.

Bhattacherjee, A. (2002). Individual trust in online firms: Scale development and initial test. Journal of Management and Information Systems, 19(1), 211-41.

Black, N. J., Lockett, A., Winklhofer, H., \& McKechnie, S. (2002). Modelling consumer choice of distribution channels: An illustration from financial services. The International Journal of Bank Marketing, 20(4), 161-73.

Calisir, F., \& Gumussoy, C. A. (2008). Internet banking versus other banking channels: Young consumers' view. International Journal of Information Management, 28(3), 215-221.

Celik, H. (2008). What determines Turkish customers' acceptance of internet banking? International Journal of Bank Marketing, 26(5), 353-70.

Chan, S. C., \& Lu, M. T. (2004). Understanding internet banking adoption and use behavior: A Hong Kong perspective.

Chang, M. K., Cheung, W., \& Lai, V. S. (2005). Literature derived reference models for the adoption of online shopping. Information and Management, 42(4), 543-559.

Chang, T. Y. (2003). Dynamics of banking technology adoption: An application to internet banking. University of Warwick, Coventry.

Chau, K. Y., Patrick., Lai, S. K., \& Vincent. (2003). An empirical investigation of the determinants of user acceptance of Internet Banking. Journal of Organizational Computing and Electronic Commerce, 
13(2), 123-145.

Chau, P.Y. K. (2001). Influence of computer attitude and self-efficacy on IT usage behavior. Journal of End User Computing, 13(1), 26-33.

Cheah, C. M., Teo, A. C., Sim, J. J., Oon, K. H., \& Tan, B. I. (2011). Factors affecting Malaysian mobile banking adoption: An empirical analysis. International Journal of Network and Mobile Technologies, 2(3), 149-160.

Chen, Y. H. \& Barnes, S. (2007). Initial trust and online buyer behavior. Industrial Management and Data Systems. 107 (1), 21-36.

Cheng, T.C. E., \& Lam, D.Y. C., \& Yeung, A. C. L. (2006). Adoption of internet banking: An empirical study in Hong Kong. Decision Support Systems, 42(3), 1558-1572.

Chin, W. C., \& Todd, P. A. (1995). On the use, usefulness and ease of use of structural equation modelling in MIS research: A note of caution. MIS Quarterly, 19(2), 237-46.

Chong, A. Y. L., Ooi, K. B., Lin, B., \& Tan, B. I. (2010). Online banking adoption: An empirical analysis. International Journal of Bank Marketing, 28(4), 267-287.

Chung, N., \& Kwon, S. J. (2009). The effects of customers' mobile experience and technical support on the intention to use mobile banking. Cyber Psychology and Behavior, 12(5), 539-43.

Chung, W., \& Paynter, J. (2002). An evaluation of internet banking in New Zealand. Proceedings of the 35th Annual Hawaii International Conference on System Sciences, January, HICSS -35.

Clemes, M. D., Brush, G. J., \& Collins, M. J. (2011). Analyzing the professional sport experience: A hierarchical approach. Sport Management Review, 14(4), 370- 388.

Cohen, A., \& Einav, L. (2007). Estimating risk preferences from deductible choice. American Economic Review, 97(3), 745-785.

Conner, M., \& Abraham, C. (2001). Conscientiousness and theory of planned behavior: Towards a more complete model of the antecedents of intentions and behavior. Personality and Social Psychology Bulletin, 27(11), 1547-1561.

Davis, F. (1989). Perceived usefulness, perceived ease of use, and user acceptance of information technology. MIS Quarterly, 13, 319-340.

DeVellis, R. F. (1991). Scale Development-Theory and Applications. London: SAGE.

Doll, W. J., Henddrickson, A., \& Deng, X. (1998). Using Davis's perceived usefulness and ease-of-use instruments for decision making: A confirmation and multi-group invariance analysis. Decision Science, 29(4), 839-69.

Eastin, M. (2002). Diffusion of E-commerce: An Analysis of the Adoption of Four E-commerce Activities. Telemetric and Informatics, 19(3), 251-267. 
Eriksson, K., Kerem, K. \& Nilsson, D. (2005). Customer acceptance of internet banking in Estonia. International Journal of Bank Marketing, 23(2), 200-16.

Euromonitor International (2012). Surging broadband access underpins lagging mobile banking in Malaysia. London: Euromonitor International.

Euromonitor International (2015). Emerging focus: Rising internet penetration in emerging market economies represents long-term opportunities. London: Euromonitor International.

Featherman, M. S., \& Pavlou, P. A. (2003). Predicting e-services adoption: A perceived risk facets perspective. International Journal of Human Computing Studies, 59(4), 451-474.

Field, A. P. (2005). Discovering statistics using SPSS (2nd ed.). London: SAGE.

Fishbein, M., \& Ajzen, I. (1975). Belief, attitudes, intention and behavior: An introduction to theory and research. Reading MA: Addision-Wasely.

Foon, Y. S., \& Fah, B. C. Y. (2011). Internet banking adoption in Kuala Lumpur: An application of UTAUT model. International Journal of Business and Management, 6(4), 161-167.

Garson, G. D. (2011) Multiple regression. Retreived from: http://www2.chass.ncsu.edu/garson/PA765/ regress.htm.

Gerrard, P., \& Cunningham, J. B. (2003). The diffusion of Internet banking among Singapore consumers. International Journal of Bank Marketing, 21(1), 16-28.

Gikandi, J. W., \& Bloor, C. (2010). Adoption and effectiveness of electronic banking in Kenya. Electronic commerce research and applications, 9(4), 277-282.

Goles, T., Lee, S. J., Rao, S. V., \& Warren, J. (2009). Trust violations in electronic commerce: Customer concerns and reactions. Journal of Computer Information Systems, 49(1), 1-9.

Gounaris, S., \& Koritos, C. (2008). Investigating the drivers of internet banking adoption decision. International Journal of Bank Marketing, 26(5), 282-304.

Grabner, K. S., \& Faullant, R. (2008). Consumer acceptance of internet banking: The influence of internet trust. International Journal of Bank Marketing, 26(7), 483-504.

Guriting, P., \& Ndubisi, N. O. (2006). Borneo online banking: Evaluating customer perceptions and behavioral intention. Management Research News, 29(2), 6-15.

Hernandez, J.M. C., \& Mazzon, J. A. (2007). Adoption of internet banking: Proposition and implementation of an integrated methodology approach. International Journal of Bank Marketing, 25(2), 72-88.

Holsapple, C. W., \& Sasidharan, S. (2005). The dynamics of trust in B2C e-commerce: A research model and agenda. Information System E-business Management, 3(4), 377-403.

Hoppe, R., Newman, P., \& Mugera, P. (2001). Factors affecting adoption of internet banking in South Africa: A comparative study. University of Cape Town. 
Howcroft, B., Hamilton, R., \& Hewer, P. (2002). Consumer attitude and the usage and adoption of homebased banking in the United Kingdom. The International Journal of Bank Marketing, 20(3), 111-121.

Hu, P. J. H., Chau, P. Y., \& Sheng, O. R. L. (2002). Adoption of telemedicine technology by health care organizations: An exploratory study. Journal of organizational computing and electronic commerce, 12(3), 197-221.

Jahangir, N., \& Begum, N. (2008). The role of perceived usefulness, perceived ease of use, security and privacy, and customer attitude to engender customer adaption in the context of electronic banking. Africa Journal of Business Management, 2(1), 32-40.

Jaruwachira, T. B., \& Fink, D. (2005). Internet banking adoption strategies for development country: The case of Thailand. Internet Research, 15(3), 295-311.

Jarvenpaa, S. L., Tractinsky, N., \& Saarinen, L. (1999). Consumer trust in an internet store: A cross cultural validation. Journal of Computer-Mediated Communication, 5(2), 1-35.

Jayawardhena, C., \& Foley, P. (2000). Changes in the banking sector: The case of internet banking in the UK. Internet Research: Electronic Networking Applications and Policy, 10(1), 19-30.

Jeyaraj, A., Rottman, J. W., \& Lacity, M. C. (2006). A review of the predictors, linkages and biases in IT innovation adoption research. Journal of Information Technology,21(1), 1-23.

Jin, B. H., Park, J. Y., \& Kim, J. Y. (2008). Cross cultural examination of the relationships among firm reputation, e-satisfaction, e-trust, and e-loyalty. International Marketing Review, 25(3), 324-337.

Johnson, R. D., \& Marakas, G. M. (2000). Research reports: The role of behavior modeling in computer skills acquisition: Towards refinement of the model. Information Systems Research, 11(4), 402-17.

Jun, M., \& Cai, S. (2001). The key determinants of internet banking service quality: A content analysis. International Journal of Bank Marketing, 19(7), 276-91.

Karem, K. (2003). Adoption of Electronic Banking: Underlying Consumer Behavior and Critical Success Factors, Case of Estonia. Tallinn Technical University.

Karjaluoto, H., Mattila, M., \& Pento, T. (2002). Factors underlying attitude formation towards online banking. International Journal of Bank Marketing, 20(6), 261-72.

Kim, H. W., Chan, H. C. \& Gupta, S. (2007). Valueđbased adoption of mobile internet: An empirical investigation. Decision Support Systems, 43, 111- 26.

Kuisma, T., Laukkanen, T., \& Hiltunen, M. (2007). Mapping the reasons for resistance to internet banking: A means-end approach. International Journal of Information Management, 27(2), 75-85.

Laforet, S., \& Li, X. (2005). Consumers' attitudes towards online and mobile banking in China. International Journal of Bank Marketing, 23(5), 362-380.

Lai, V. S., \& Li, H. (2005). Technology acceptance model for internet banking: An invariance analysis. 
Information and Management, 42(2), 373-86.

Lee, M. C. (2008). Factors influencing the adoption of internet banking: An integration of TAM and TPB with perceived risk and perceived benefit. Electronic Commerce Research and Applications, 8, 130-141.

Lee, M., McGoldrick, P., Keeling, K., \& Doherty, J. (2003). Using ZMET to explore barriers to the adoption of $3 \mathrm{G}$ mobile banking services. International Journal of Retail E Distribution Management, $31(6 / 7), 340-8$.

Liao, S., Shao, Y. P., Wang, H., \& Chen, A. (1999). The adoption of virtual banking: An empirical study. International journal of information management, 19(1), 63-74.

Liao, Z., \& Cheung, M. T. (2002). Internet-based e-banking and consumer attitudes: An empirical study. Information and Management, 39(4), 283-95.

Lichtenstein, S., \& Williamson, K. (2006). Understanding consumer adoption of Internet banking: An interpretive study in the Australian banking context. Journal of Electronic Commerce Research, $7(2), 50-66$.

Littler, D., \& Melanthiou, D. (2006). Consumer perceptions of risk and uncertainty and the implications for behaviour towards innovative retail services: The case of internet banking. Journal of Retailing and Consumer Services, 13(6), 431-443.

Lu, J., Yu, C. S., Liu, C., \& Yao, J. E. (2003). Technology acceptance model for wireless internet. Internet Research, 13(3), 206-22.

Luarn, P., \& Lin, H. H. (2005). Toward an understanding of the behavioral intention to use mobile banking. Computers in Human Behavior, 21(6), 873-91.

Maditinos, D., Chatzoudes, D., \& Sarigiannidis, L. (2013). An examination of the critical factors affecting consumer acceptance of online banking: A focus on the dimensions of risk. Journal of Systems and Information Technology, 15, 97-116.

Malhotra, N. K. (2003). Marketing research: An applied orientation ( $3^{\text {rd }}$ ed.). Upper Saddle River, N.J: Pearson Education Inc.

Marr, N. E., \& Prendergast, G. P. (1993). Consumer adoption of self-service technologies in retail banking. International Journal of Bank Marketing, 11 (1), 3-10.

Morrison, D. G. (1979). Purchase intentions and purchase behavior. Journal of Marketing, 43, 65-74.

Morwitz, V. G., Steckel, J. H., \& Gupta, A. (2006). When Do Purchase Intentions Predict Sales? Retreived from: http://w4.stern.nyu.edu/emplibrary/Marketing 152006 Morwitz Steckel \%26 Gupta.pdf

Nasri, W. (2011). Factors influencing the adoption of internet banking in Tunisia. International Journal of Business and Management, 6(8), 143-160.

Ndubisi, N. O., \& Sinti, Q. (2006). Consumer attitudes, systems characteristics and internet banking 
adoption in Malaysia. Management Research News, 29(2), 16-27.

Ong, H. B., \& Cheng, M. Y. (2003). Success factors in e-channels: The Malaysian banking scenario. International Journal of Bank Marketing, 21(6), 369-377.

Pikkarainen, K., Pikkarainen, T., Karjaluoto, H., \& Pahnila, S. (2004). Consumer acceptance of online banking: An extension of the technology acceptance model. Internet Research, 14(3), 224-235.

Polatoglu, V. N., \& Ekin, S. (2001). An empirical investigation of the Turkish consumers' acceptance of internet banking services. International Journal of Bank Marketing, 19(4), 156-65.

Poon, W. C. (2007). Users' adoption of e-banking services: The Malaysian perspective. Journal of Business and Industrial Marketing, 23, 59-69.

Raman, A., \& Don, Y. (2013). Preservice teachers' acceptance of learning management software: An application of the UTAUT2 model. International Education Studies, 6(7), 157-164.

Ramsay, J., \& Smith, M. (1999). Managing consumer channel usage in the Australian banking sector. Managerial Auditing Journal, 14(7), 32-33.

Rogers, E. M. (2003). Diffusion of Innovations. New York, London: Free Press.

Rotchanakitumnuai, S., \& Speece, M. (2003). Barriers to Internet banking adoption: A qualitative study among corporate customers in Thailand. International Journal of Bank Marketing, 21(6/7), 312-323.

Sathye, M. (1999). Adoption of internet banking by Australian consumers: An empirical investigation. International Journal of Bank MarketinG, 17(7), 324-34.

Saunders, M., Lewis, P., \& Thornhill, A. (2012). Research Methods for Business Students. 6th ed. Essex: Pearson Education Limited.

Shanmugam, B., \& Guru, K. (2000). E-banking developments in Malaysia: Prospect and problems. Journal of International Banking LaW, 15(10), 250-256.

Shih, Y., \& Fang, K. (2004). The use of a decomposed theory of planned behavior to study internet banking in Taiwan. Internet Research, 14(3), 213-223.

Singh, A. M. (2004). Trends in South African internet banking. Aslib Proceedings: New Information Perspectives, 56(3), 187-96.

Singhal, D., \& Padhmanabhan, V. (2008). A study on customer perception towards internet banking: Identifying major contributing factors. The Journal of Nepalese Business Studies, 5(1).

Siriluck, R., \& Speece, M. (2003). Barriers to internet banking adoption: A qualitative study among corporative customers in Thailand. International Journal of Bank Marketing, 21(6), 312-23.

Srivastava, R. J. (2007). Customer's perception on usage of internet banking. International Marketing, $3(4), 67-73$. 
Subsorn, P., \& Limwiriyakul, S. (2012). A comparative analysis of internet banking security in Thailand: A customer perspective. Procedia Engineering, 32, 260-272.

Tan, M., \& Teo, T. S. H. (2000). Factors influencing the adoption of internet banking. Journal of the Association for Information Systems, 1(5), 1-44.

Taylor, S., \& Todd, P. A. (1995). Understanding information technology usage: A test of competing models. Information System Research, 6(2), 144-76.

Tirtiroglu, E., \& Elbeck, M. (2008). Qualifying purchase intentions using queueing theory. Journal of Applied Quantitative Methods, 3(2), 167-178.

Venkatesh, V., \& Davis, F. D. (1996). A model of the antecedents of perceived ease of use: Development and test. Decision Sciences, 27(3), 451-81.

Venkatesh, V., \& Davis, F. D. (2000). A theoretical extension of the technology acceptance model: Four longitudinal field studies. Management Science, 46(2), 186-204.

Venkatesh, V., \& Morris, M. G. (2000). Why do not men ever stop to ask for directions? Gender, social influence, and their role in technology acceptance and usage behavior. MIS Quarterly, 24(1), 115-39.

Venkatesh, V., Morris, M. G., Davis, G. B., \& Davis, F. D. (2003). User acceptance of information technology: Towards a unified view. MIS Quarterly, 27(3), 425-78.

Vijayasarathy, L. R. (2003). Shopping orientations, product types and internet shopping intentions. Electronic Markets, 13(1), 67-79.

Wang, S., \& Barnes, S. (2007). Exploring the Acceptance of Mobile Auctions in China: Proceedings of the Sixth International Conference on the Management of Mobile Business. Toronto, Canada.

Wang, Y. S., Wang, Y. M., Lin, H. H., \& Tang, T. I. (2003). Determinants of user acceptance of internet banking: An empirical study. International Journal of Service Industry Management, 14(5), 501-19.

Wei, T. T., Marthandan, G., Chong, A.Y. L., Ooi, K. B., \& Arumugam, S. (2009). What drives Malaysian m-commerce adoption? Empirical analysis. Industrial Management and Data Systems, 109(3), 370-88.

Wisniewski, J. R., Zougman, A., Nagaraj, N., \& Mann, M. (2009). Universe sample preparation method for proteome analysis. Nature Methods. 6, 359-362.

Yaghoubi, N. M., \& Bahmani, E. (2010). "Factor affecting the adoption of Online Banking: An integration of Technology Acceptance Model and Theory of Planned Behaviorl. Pakistan Journal of Social Sciences, 7(3), 231-236.

Yang, M. H., Chandlrees, N., Lin, B., \& Chao, H. Y. (2009). The effect of perceived ethical performance of shopping web sites on consumer trust. Journal of Computer Information Systems, 50(1), 15-24.

Yiu, C. S., Grant, Y. K., \& Edgar, D. (2007). Factors affecting the adoption of internet banking in Hong Kong - implications for the banking sector. International Journal of Information Management, 2, 336-351. 
Yousafzai, S. Y., Pallister, J. G., \& Foxall, G. R. (2003). A proposed model of e-trust for electronic banking. Technovation, 23(11), 847-860.

Yuen, Y. Y., Yeow, P. H. P., \& Lim, N. (2014). Internet banking acceptance in the United States and Malaysia: A cross-cultural examination. Marketing Intelligence $\mathcal{E}$ Planning, 33(3), 292-308. 